\title{
CHARLES MASON AND THE BURLINGTON-NORTHWESTERN NARROW GAUGE RAILROAD
}

\author{
By Willard I. Toussaint \\ Associate Professor of History \\ Adrian College, Adrian, Michigan
}

In the twenty years immediately following the Civil War there were two different trends in the building of railroad track in the United States. This was the period in which most American railroads adopted what is called the standard gauge track, the distance between the inside running edges of the rails being 4 feet, $81 / 2$ inches. ${ }^{1}$ The use of this width was largely accidental. The first English locomotives were built to draw coal wagons, whose axles had become so standardized that when the wagons were set on rails, the distance between the wheels was always 4 feet, $81 / 2$ inches. Consequently, most English commercial railroads laid their tracks to accommodate this gauge, and by 1880 it was more commonly used than any other width. Since many early American builders purchased English engines, they naturally built their roads to fit them. ${ }^{2}$

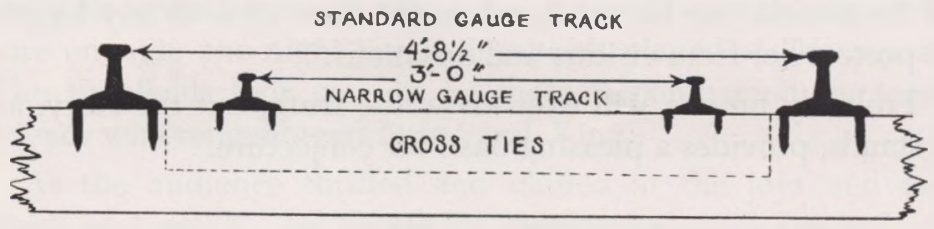

At the same time, however, some American promoters built more than 5,000 miles of narrow gauge track with only 3 feet, 6 inches or less between the rails. ${ }^{3}$ In Iowa nearly twenty such lines were planned and fourteen actually built, using 575 miles of narrow gauge track. Interest in the narrow gauge lines was initially sparked by the fact that they required less grading and less expensive equipment than the broad gauge

\footnotetext{
${ }^{1}$ Robert S. Henry, This Fascinating Railroad Business (New York, 1946 ), p. 37.

${ }^{2}$ Robert S. Russel, A History of the American Economic Systcm (New York, 1964), p. 157.

${ }^{3}$ Henry, op. cit., p. 37.
} 
lines. Too, many isolated communities, which the main railroad systems had bypassed, promoted the cause of the narrow gauge in the hope for train service. ${ }^{4}$

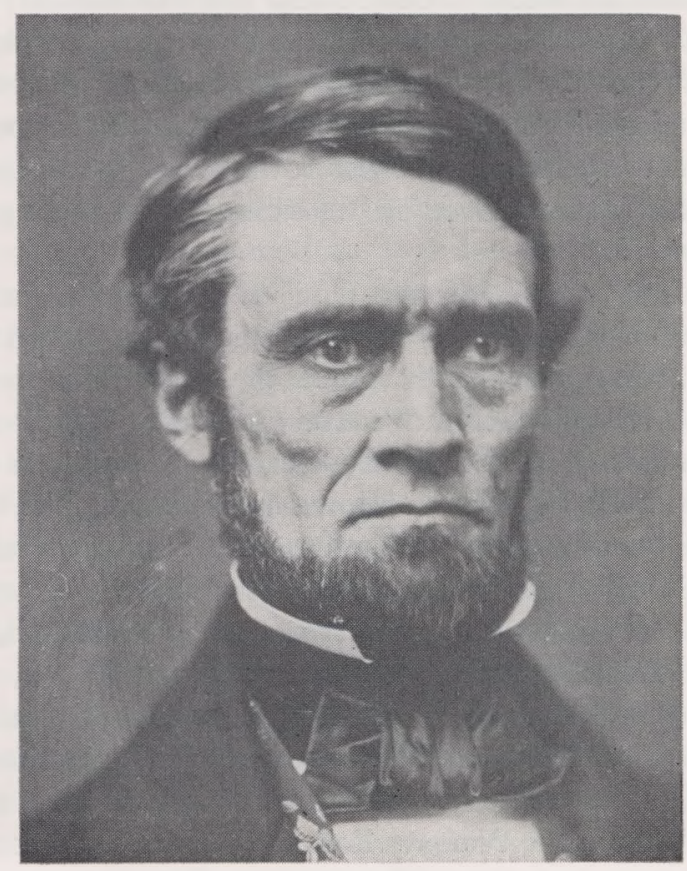

Charles Mason

According to an Iowa newspaper of the period, Charles Mason of Burlington was one of the first to be interested in constructing such narrow gauge railroads in the southern part of the state. ${ }^{5}$ A native of New York and a West Point graduate, Mason had studied law and practiced it briefly in the East after his resignation from the army. He came to Iowa Territory in 1837, settling in Burlington. Although he was a lawyer and became both a federal judge and Commissioner

"Ben Hur Wilson, "Iowa and the Narrow Gauge," Palimpsest, XIII (April, 1932), 141-143.

${ }_{5}^{5}$ Burlington Hawkeye, September 24, 1875. 
of Patents in Washington, he was also a land speculator. After * the Civil War he engaged in numerous business ventures in Burlington, including banking and the promotion of companies to provide the city with its first public transportation and a municipal water supply. ${ }^{\circ}$ The story of Mason's involvement with the construction of a narrow gauge railroad not only illustrates how one business promoter of that day successfully meshed his interests in banking and land speculation with the new venture, but it also reveals some of the problems which management faced in financing and building narrow gauge lines.

For several years after the Civil War, the citizens of Burlington had contemplated construction of a railroad through the area immediately northwest of their city. Finally in 1872 a railroad company organized to construct a narrow gauge line through that region. John Gear, Charles Mason's brotherin-law and later Governor of lowa, was president of the company, the Burlington and Northwestern. ${ }^{7}$ Mason took $\left.\$ 2,000\right)$ in stock in an organization called the Narrow Gauge Land Company, designed to profit from the rise in land values wherever the railroad company laid its track. ${ }^{8}$

The Burlington and Northwestern hoped to finance the construction with aid from two sources. Soon after its organization, the management endeavored to enlist help from the Toledo, Peoria, and Warsaw Railroad, which ran from Peoria to Burlington; but the amount of proffered assistance was insufficient. The Burlington and Northwestern officials then assured the people along the proposed line that they would build the railroad if localities along the way raised funds equal to $\$ 3,500$ per mile of track.

President Gear addressed a meeting at Washington, lowa, concerning the railroad's offer. He proposed to locate the line through the region which first obtained the right of way and raised enough money to grade and tie the road from

${ }^{6}$ Emlin McClain, "Charles Mason-Iowa's First Jurist," Annals of Iowa, Third Series, IV ( January, 1901), 607.

${ }^{7}$ Burlington Hawkeye, May 23, 1875; March 22, 1872.

${ }^{8}$ Statement of Charles Mason's account with Thomas Hedge, March 31, 1871, in Mason Collected Papers and Diaries, Vol. 41, MSS in Iowa State Department of History and Archives, Des Moines, Iowa. 
Sperry, Iowa, fifteen miles from Burlington on the Burlington, Cedar Rapids, and Minnesota Railroad, to the east line of Washington County. A committee chosen to report on ways and means recommended that the amount asked for be raised by taxes in Washington County and by subscription in the townships between there and Burlington. Since more than the necessary number signed the petition for an election in IVashington County to vote on the proposed taxes, approval seemed likely. However, the financial panic and other causes that year combined to defeat the proposed aid and the railroad promoters were forced to abandon the railroad project for the time being. ${ }^{9}$

Despite this setback, Charles Mason continued to investigate the economic practicability of narrow gauge railroads in Iowa. Apparently he wrote to owners of such lines in Iowa to ascertain operating costs. One of his correspondents, W. G. Crooke, wrote from McGregor that his fifteenmile narrow gauge railroad cost $\$ 13,000$ per mile, including cost of right of way, two 15-ton locomotives, two passenger cars, and twenty-one flat cars. This, said Crooke enthusiastically, was only two thirds of what it cost to operate a broad gauge line. He pointed out too that the rolling stock on the narrow gauge did not wear the track to the same extent as ordinary rolling stock and that "we are satisfied that we can do as much business as is now done on any of our broad gauge roads at much less expense."10

By 1875 Mason and others were convinced that a narrow gauge railroad northwest of Burlington would be profitable. Mason favored a narrow gauge line because in his opinion the lighter cars would have much less dead weight and therefore would cost less to operate than those on the broad gauge. ${ }^{11}$ Thomas Hedge, Burlington merchant, pointed out that such a line would enable Burlington to recover the trade lost when the Rock Island Railroad extended its route into Washington, Keokuk, and Louisa counties. ${ }^{12}$ Construction of a narrow gauge seemed advantageous for yet another reason-the possibility of

${ }^{8}$ Burlington Haukeye, January 6, March 22, May 23, 1875.

${ }^{10}$ W. I). Crooke to Mason, November 12, 1872, Vol. 24.

${ }^{11}$ Mason Diary, June 17, 1876, Vol. 47.

${ }^{12}$ Burlington Hawkeye, March 23, 1875. 
connecting with another narrow gauge railroad then being constructed across Illinois and Indiana. The promoter, George McElroy, hoped to extend his line across Ohio as far as Toledo and wrote the Burlington Hawkeye that he would be glad to connect with an Iowa narrow gauge line somewhere in western Illinois. ${ }^{13}$

Early in 1875 the towns northwest of Burlington began showing interest in the projected narrow gauge railroad through their communities. A group in Crawfordsville Township, Washington County, went on record as favoring a narrow gauge line from Burlington via Winfield, Crawfordsville, and Washington; it declared this to be the best route not only for trade with Burlington, but also with Chicago, St. Louis, and the southern markets. The next month residents of Wayne and other nearby townships in Henry County attended a similar narrow gauge meeting at Winfield. Shortly afterward, Burlington residents voted at a meeting to cooperate with the towns along the proposed route. Still another meeting followed at Crawfordsville on February 20, 1875, attended by delegates from Winfield and Burlington, who pledged financial aid to the project.

Evidence of wide-spread public interest and support led to steps in March, 1875, toward organizing a narrow gauge railroad company. Delegates came to a meeting at Morning Sun from Flint River, Franklin, Pleasant Grove, Yellow Springs, and Washington townships in Des Moines County; Scott and Wayne townships in Henry County; Crawfordsville township in Washington County; and Elm Grove and Morning Sun townships in Louisa County. The group elected one representative from each township to a committee charged with preparing Articles of Incorporation. Capital stock was set at $\$ 300,(000$, divided into $\mathrm{sh}$ a res of $\$ 100$, and the company opened books for subscriptions to the Burlington and Northwestern Narrow Gauge Railroad. Thomas Hedge became the first president and R. M. Green the secretary.

The first question to be settled was where the new company should build its line. Several meetings in Burlington, at which Mason presided, attempted to solve this. One group doubted

${ }^{13}$ George McElroy to Burlington Hawkeye, April 4, 1875. 
that they could raise enough money to build on any route. Another faction wished to build as far north as Sperry in Des Moines County, and eventually northwest to Winfield. A third group, which Mason supported, favored building to Mediapolis, three miles beyond Sperry, before building to Winfield. Mason's plan finally prevailed. This decision as to the route brought about a change of membership on the board of directors. Two directors, Archibald Jackson of Elm Grove and Henry Wallace of Morning Sun, resigned because the route chosen for the railroad would not touch their towns. The board elected John Gear and Charles Mason to fill the vacancies.

To put their plans into operation, the directors negotiated various contracts. One was an agreement with the receiver of the Burlington, Cedar Rapids, and Minnesota Railroad to build a third rail on that line from Burlington to Mediapolis, a distance of fifteen miles. This third rail would accommodate the three-foot gauge of the proposed Burlington and Northwestern. From Mediapolis, the company proposed to build its own nineteen-mile line to Winfield. The directors let other contracts for grading, tying, and bridging. At this point the editor of the Burlington Hawkeye seemed confident that the railroad's problems were over. He wrote concerning the negotiation of contracts:

It tells us that the narrow gauge is a reality and that we have passed the period of promises and hopes deferred, which maketh the heart sick and all that sort of thing, and that we are entering upon the fruition of our hopes and the realization of promises. ${ }^{14}$

However, although the organizers of the Burlington and Northwestern had let contracts, they found it difficult to raise the necessary cash to pay for construction, rails, and rolling stock. The Articles of Incorporation called for $\$ 300,000$ in stock sales to meet these expenses. By April 10, 1875, they had raised only $\$ 60,000$, and discouraged by many refusals and much indifference, were inclined to give up the effort. Finally Burlington made a supreme effort to raise its $\$ 100,000$. quota. City merchants closed their doors at three o'clock

${ }^{14}$ Burlington Hawkeye, January 20; February 7, 18, 20; March 4; August 7; September 24, 26; November 3, 1875; July 2, 1876. 
May 3 to devote the rest of the day to the interests of the narrow gauge. Then a mass meeting raised $\$ 90,000$ of the town's share necessary to launch the enterprise. When the company appealed for still more funds, Burlington raised its subscription to $\$ 110,000 .{ }^{15}$ Charles Mason responded to a special plea from President Hedge to purchase stock as a public-spirited citizen, ${ }^{16}$ and took twenty shares. ${ }^{17}$

Citizens outside Burlington proved even more reluctant to purchase stock in the projected line. By late summer of 1875 , Winfield and intermediate points had contributed only $\$ 55$,000. In a last effort, Burlington and Winfield together raised the total amount to $\$ 156,000$. Although these subscriptions would pay for construction to Winfield, they were far short of what the company needed for other expenses. Finally the company decided to omit the $\$ 300,000$ clause in its Articles and to proceed with plans, in the hope that more money would be forthcoming as the road became a reality. ${ }^{18}$

Some of the company officers sought means to raise funds for rails and rolling stock. A 5 per cent call on the stockholders would bring in enough money to meet the payments on contracts until April, 1876, but nothing from that source until after April would pay for rails and locomotives. President Hedge told Mason that he himself was willing to furnish $\$ 20,000$ or $\$ 25,000$ for that purpose, but he had found nobody willing to contribute the remaining $\$ 60,000$ to $\$ 80,000$ which the company needed in addition to subscriptions. Hedge, on the other hand, was unwilling to make contracts for rails and rolling stock on his personal obligations, a necessary arrangement because the rail and locomotive companies would not take the obligations of the Burlington and Northwestern.

In order to raise the required sum for rails, Hedge proposed to Mason that they each advance the company $\$ 30,000$; on that basis, he thought he could contract for 1,300 tons of rails. In the belief that the price of iron would never be lower and would soon increase in price, Hedge thought that he and

${ }^{15}$ Ibid., April 18; May 1, 4; December 23, 1875.

${ }^{16}$ Thomas Hedge to Mason, April 26, 1875; Vol. 41.

${ }^{17}$ Stock receipt, October 20, 1875, for 20 shares of stock in the Burlington and Northwestern Railroad, Vol. 41.

${ }_{18}^{8}$ Burlington Hawkeye, August 7, December 23, 1875; July 2, 1876. 
Mason could compensate themselves for the risk involved by purchasing rails at the current price and later selling them to the company at a higher market price. Mason may have consented to some arrangement of this sort, for the president later wrote him about the price of the rails: "I name the price to you because your interest in it is identical with mine. I wish you would not name it to anyone." ${ }^{\text {1 }}$

The directors then met to contrive means for buying locomotives and cars. They offered stockholders various inducements to pay for their shares before installments were due. Subscribers who paid in advance could have a 10 per cent yearly deduction on what they owed the railroad. One suggestion was that the stockholders give their notes prior to assessments on their subscriptions, enabling the company to use the notes as collateral for borrowing money before collecting on subscriptions. The Burlington subscribers met these offers to about half the amount of their stock, nearly $\$ 55,000{ }^{20}$

Greatly encouraged by the stockholders' co-operation, Mason and Hedge went East on buying trips early in 1876. In January, Mason visited Philadelphia to investigate the size and types of locomotives available. This was evidently an exploratory trip, since he made no purchases. ${ }^{21}$ Hedge, however, later made a buying trip to Paterson, New Jersey, and Philadelphia, where the companies offered him two 17-ton engines for $\$ 6,500$ and $\$ 7,000$ each. He bought one locomotive, one passenger coach, one combined passenger and baggage car, and forty freight cars. ${ }^{22} \mathrm{He}$ estimated that this was all the rolling stock needed to equip the railroad for operations to Winfield, with the exception of one more engine and possibly some additional freight cars. Contracts with manufacturers of this rolling stock stipulated that the Burlington and Northwestern pay cash for the items on delivery.

The shortage of funds, created partly because of the stockholders' delinquency in meeting assessments on their subscriptions, posed the next problem: How would the Burling-

19 Thomas Hedge to Mason, January 19, March 1, 1876, Vol. 27.

${ }^{20}$ Burlington Hawkeye, July 2, 1876.

${ }^{21}$ Mason Diary, January 15, 1876, Vol. 49.

22 Thomas Hedge to Mason, March 4, 1876, Vol. 27. 
ton and Northwestern be able to pay these Eastern creditors? - The company was without funds to pay these obligations when they were due. On some of them, creditors positively refused an extension of time. On others, the Burlington and Northwestern secured extension of payment when certain directors became personally liable as endorsers. However, upon maturity of these extended notes, the company was in no better position to pay than before. ${ }^{23}$

The Burlington and Northwestern also faced the problem of how to pay Mason and Hedge for the rails they had purchased. The president, during his Eastern trip, had purchased from the Cambria Iron Works in Philadelphia 1,300 tons of 30 -pound rails at $\$ 42$ per gross ton. The company was to make delivery in four shipments during April, May, and June via Chicago. Freight to that point was $\$ 5$ per ton and $\$ 2$ per ton more to Burlington, making a total cost of less than $\$ 50$ per ton, $\$ 2.50$ less than anyone except Hedge had believed possible. The Cambria Company was to draw on Hedge at Philadelphia or New York at 10 days' sight from shipment of each lot. ${ }^{24}$

Naturally Hedge and Mason were anxious to have the Burlington and Northwestern compensate them for the obligation they had assumed in purchasing rails for the company. Mason favored borrowing the money needed to pay current debts, repaying it as the railroad collected subscriptions. He proposed issuing bonds amounting to not more than $\$ 5,000$ per mile to use as collateral for a loan, taking a temporary mortgage on the railroad as security for the bonds. Mason thought that this loan would not only pay the line's financial obligations, but enable it to continue to Winfield. He thought this was a better decision than to stop work on the line until the company collected unpaid subscriptions.

The directors, deciding to follow Mason's suggestion to borrow money, issued $\$ 100,000$ in ten-year, 8 per cent bonds. Except for eight $\$ 100$ bonds, they sold them at 50 cents on the dollar, hoping to raise $\$ 50,000$ with which to pay off the company's debts and to proceed with construction to Win-

${ }^{23}$ Burlington Hawkeye, June 21, 1877.

${ }^{24}$ Thomas Hedge to Mason, March 1, 1876, Vol. 27. 
field.$^{25}$ But although these bonds were backed by a mortgage on the railroad, they did not sell rapidly; the company raised only $\$ 35,000$ of the expected $\$ 50,000$. Mason then contributed $\$ 10,000$, taking $\$ 20,000$ in bonds, and was willing to advance more if necessary to put the road through to Winfield. ${ }^{26}$

Perhaps Mason's contribution did provide the necessary impetus. In September, 1876, Mason wrote that the line was making progress, laying rails between Mediapolis and Winfield. The next month they were as far as Yarmouth, halfway between the two towns. The line reached Winfield by December, 1876. At each of the stations-Winfield, Mt. Union, Yarmouth, Roscoe, and Burlington-depots and stockyards were built, with turntables and water towers at the termini of the road. The total cost of these buildings and fixtures was $\$ 7,007.88 .{ }^{27}$

The still unanswered question was whether the railroad would do enough business to pay its debts and meet expenses. At first the enterprise looked profitable. The line began by running one train a day from Winfield to Burlington, carrying lumber and coal to Winfield and stock and passengers on the return trip. Mason wrote that the company could not handle as promptly as necessary all the business offered it; however, Mason expected an eventual decline in business because of a scant crop in 1876. This proved to be the case. Because the region through which the railroad ran had almost an entire crop failure in 1876, followed by a similar one the next year, railroad business declined.

The directors realized the economic necessity of extending the line beyond Winfield. They derived all revenue on the Burlington-Winfield line, a distance of thirty-four miles, from less than fourteen miles of track. For fifteen miles out of Burlington, the line ran over the track of the Burlington, Cedar Rapids, and Minnesota Railroad by means of a third rail, for which the Burlington and Northwestern paid a yearly rental of $\$ 400$ per mile. For five miles beyond the third rail, the narrow gauge had no patronage. Thus twenty out of thirty-

${ }^{25}$ Burlington Hawkeye, July 2, 1876; June 21, 1877.

${ }^{26}$ Mason Diary, August 22, September 18, 1876, Vol. 49.

${ }^{27}$ Burlington Hawkeye, January 4, June 21, 1877. 


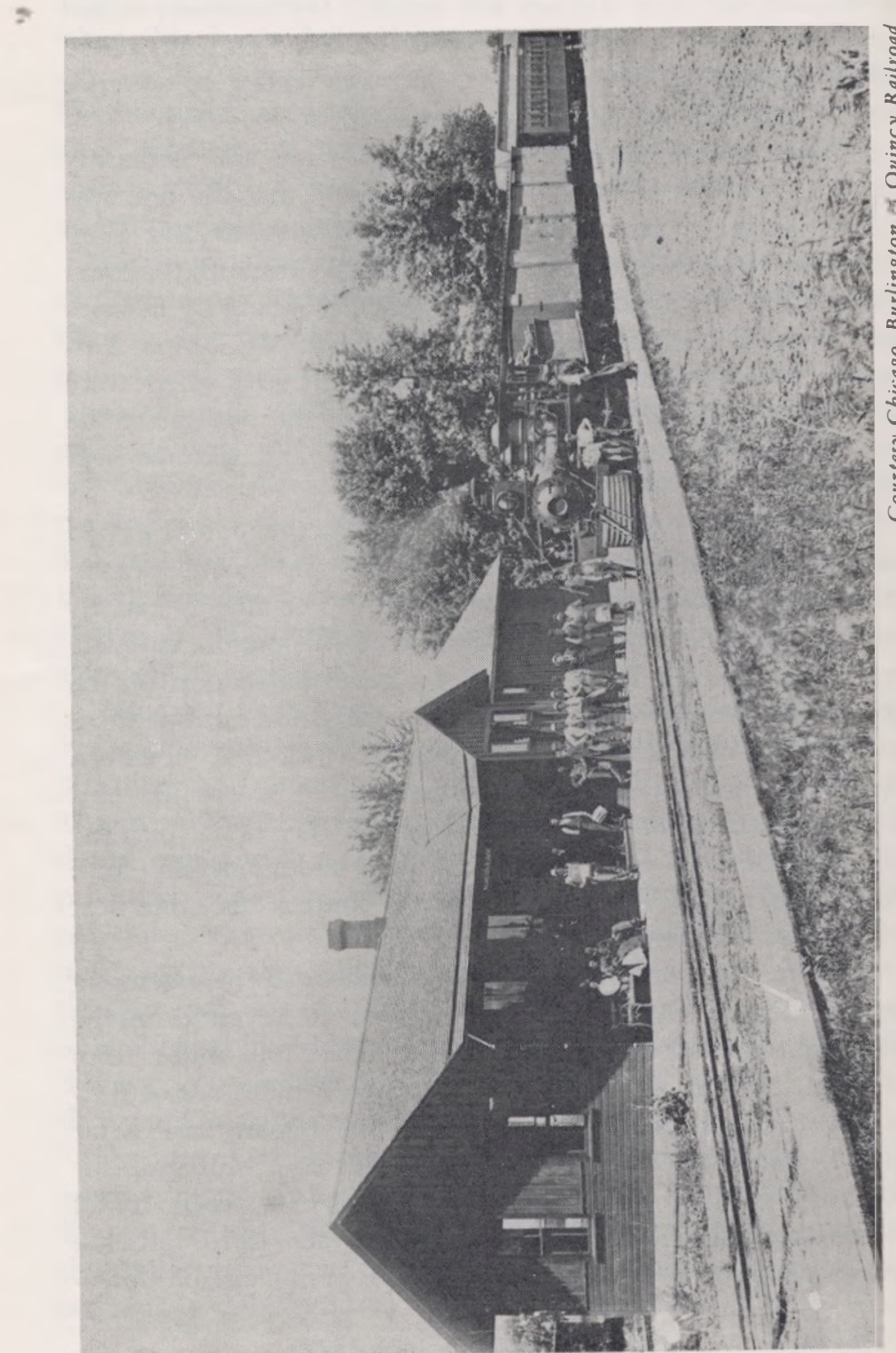

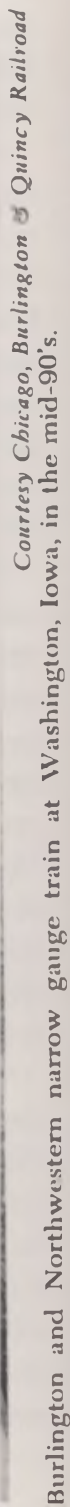


four miles were non-paying, and the railroad men estimated that where the non-paying section of a road was more than half, the disproportion was too great for profit. The remedy, then, was to extend the road. Hedge, faced with this problem, declined re-election as president of the company, and the board of directors elected Mason in his place.

Mason hoped that townships west or northwest of Winfield would extend financial aid to the railroad to facilitate its construction through their communities. He evidently expected to build through whatever townships voted the highest railroad taxes. He made numerous visits to Richland, Brighton, and Fremont, communities west of Winfield, to promote favorable tax elections there. ${ }^{28}$ At the same time he carried on negotiations with leaders in Crawfordsville and Washington, Iowa, ${ }^{29}$ holding out the possibility of a railroad connection with Winfield if the townships would approve a subsidy.

The tax levy finally authorized in townships directly west of Winfield did not meet the estimated needs for constructing the narrow gauge railroad there. The engineer of the Burlington and Northwestern estimated the building costs at $\$ 5,878$ per mile. ${ }^{30}$ Mason thought this would require a 5 per cent tax levy on assessed property valuation in each township. $^{31}$ F. N. Byram from Fremont wrote Mason that voters in his township would not approve it. ${ }^{32}$ S. H. Durfey held the same opinion about townships in Keokuk County. Mason commented in his diary, "We shall hardly build the road on a less tax and I shall so inform him." ${ }^{33}$

For a time it seemed as if the tax is s u e in Washington County would be no more favorably received than in Keokuk County. An election in Washington Township was adverse to the tax because of hard times and a belief that a norrow gauge railroad could not give any advantages in

${ }^{28}$ Mason Diary, December 13, 1876; November 23, 1877; March 30, June 19, July 29, 1878, Vol. 49.

${ }^{20}$ J. M. Crawford to Mason, July 1, 1878, Vol. 28; Burlington Hawkeye, July 2, 1878.

${ }^{30}$ I. T. Gerry to Mason, July 1, 1878, Vol. 28.

${ }^{31}$ Mason Diary, October 31, 1878, Vol. 49.

${ }^{32}$ F. N. Byram to Mason, August 31, 1878, Vol. 28.

${ }^{33}$ Mason Diary, October 19, 1878, Vol. 49. 
freight rates that the community did not already possess. ${ }^{34}$

- But finally the citizens of Washington Township, on a second vote, approved a subsidy to the Burlington and Northwestern. The voters stipulated, however, that the railroad company was to use subsidies collected in Washington Township exclusively to pay for work on the Winfield-Washington branch.

To raise additional funds to extend the road to Washington, the company made two new bond issues. One was a ten-year, 7 per cent issue of first mortgage bonds for $\$ 120,000$, dated August 1, 1879, and secured by a mortgage on the entire line from Burlington to Washington - the franchise, road bed, buildings, and rolling stock. The other, covering the same property, was a second mortgage issue of $\$ 83,000$ for seven years at 8 per cent. The second mortgage bonds were intended to cover the claims of the original mortgage bond holders on the Burlington to Winfield line. Then in an effort to induce stockholders to take the first mortgage bonds so as the finance extension of the road to Washington, the company put them on the market at a 20 per cent discount.

With additional revenue in prospect, the Burlington and Northwestern then made plans for constructing the line to Washington. Engineers completed surveys and began bridging, grading, and tying in the summer of 1879. Railroad rails began arriving from Atlanta in September. The line reached Crawfordsville in November and was completed to Washington by January 19, 1880. The company then began operating one regular train per day ${ }^{35}$ which took four hours to complete the entire route. ${ }^{38}$

The road proved to be a financial success. The gross earnings for the first three months of 1880 were slightly over $\$ 17$,000 . By June, 1880, the officers told the stockholders that the past fiscal year had been the most financially successful one in the history of the road, earnings being 150 per cent more than those of the previous year. ${ }^{37}$ The favorable business continued in the succeeding months. Mason noted in his diary that re-

${ }^{34}$ Ibid., September 23, 1878, Vol. 49.

${ }^{35}$ Burlington Hawkeye, May 4, 1879; June 17, 1880; July 23, September 24, November 18, 1879; January 19, 1880.

${ }^{38}$ Thomas Hedge to Mason, April 1, 17, 1880, Vol. 29.

${ }^{37}$ Burlington Hawkeye, June 17, 1880. 
Charles Mason and the Burlington-Northwestern 199

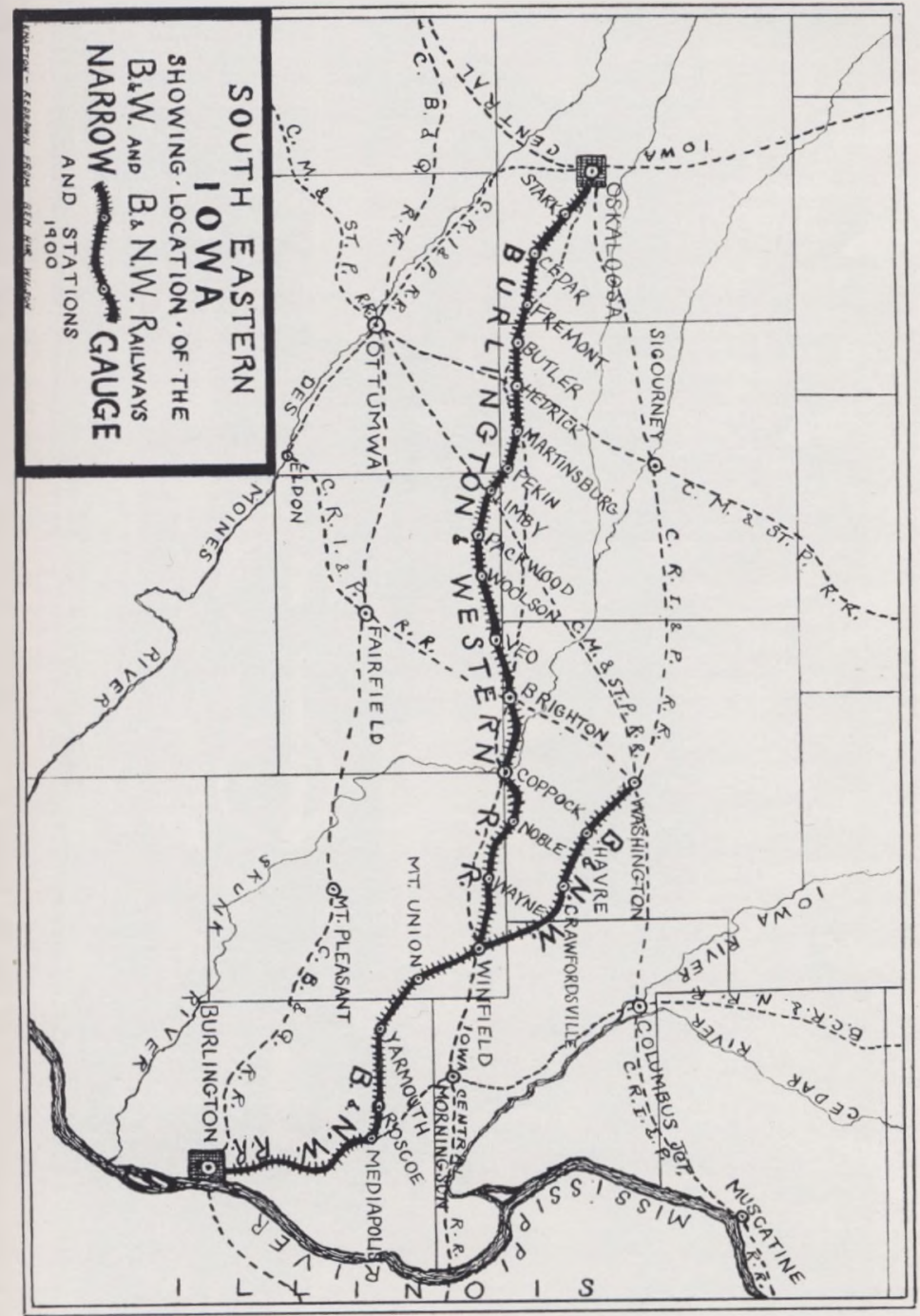




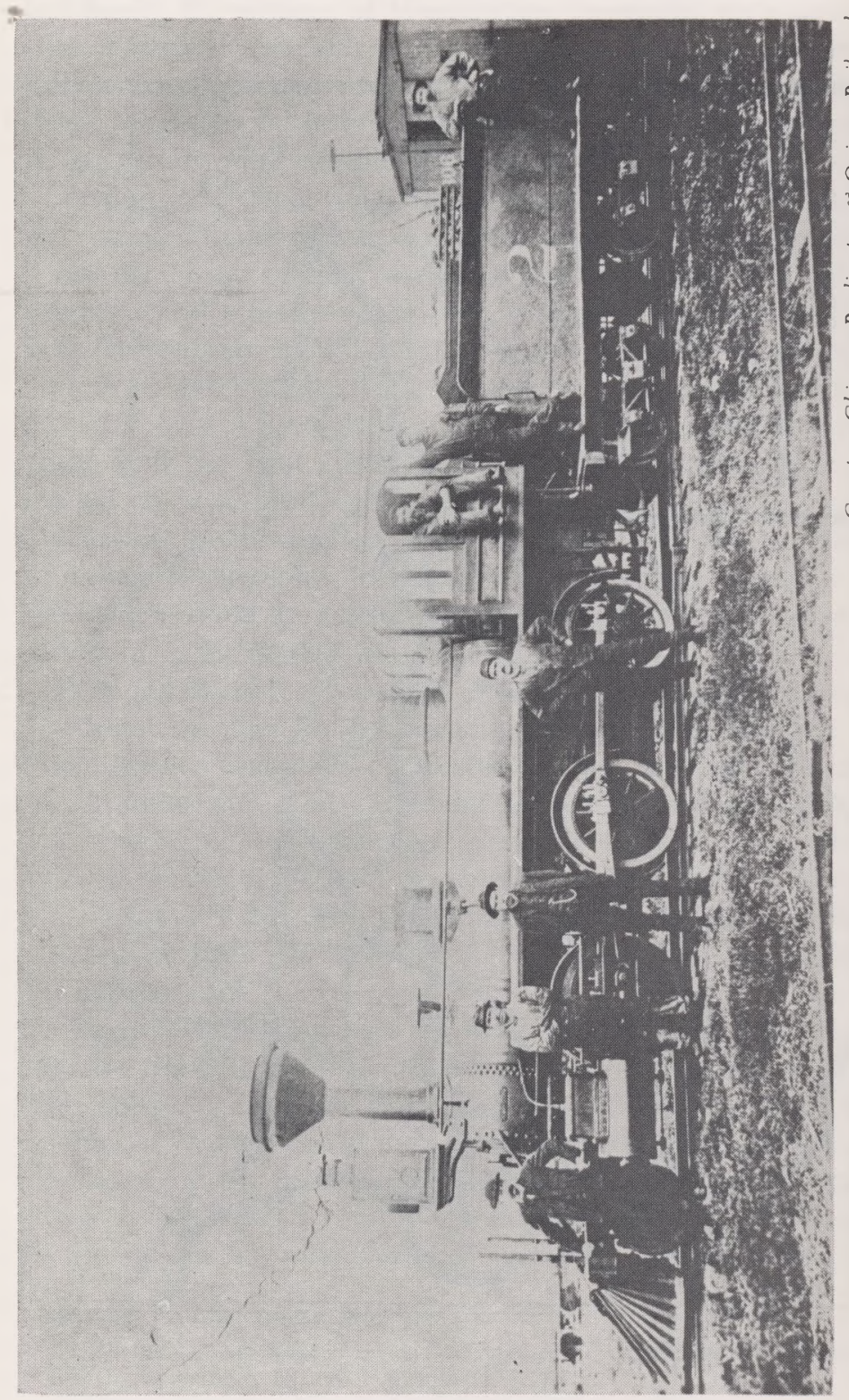

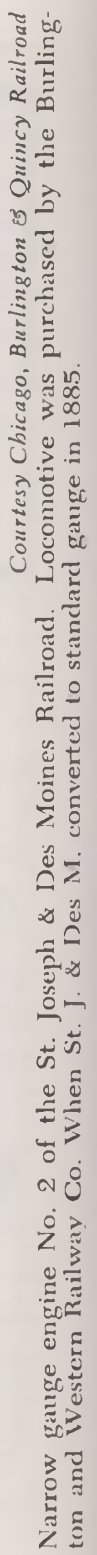




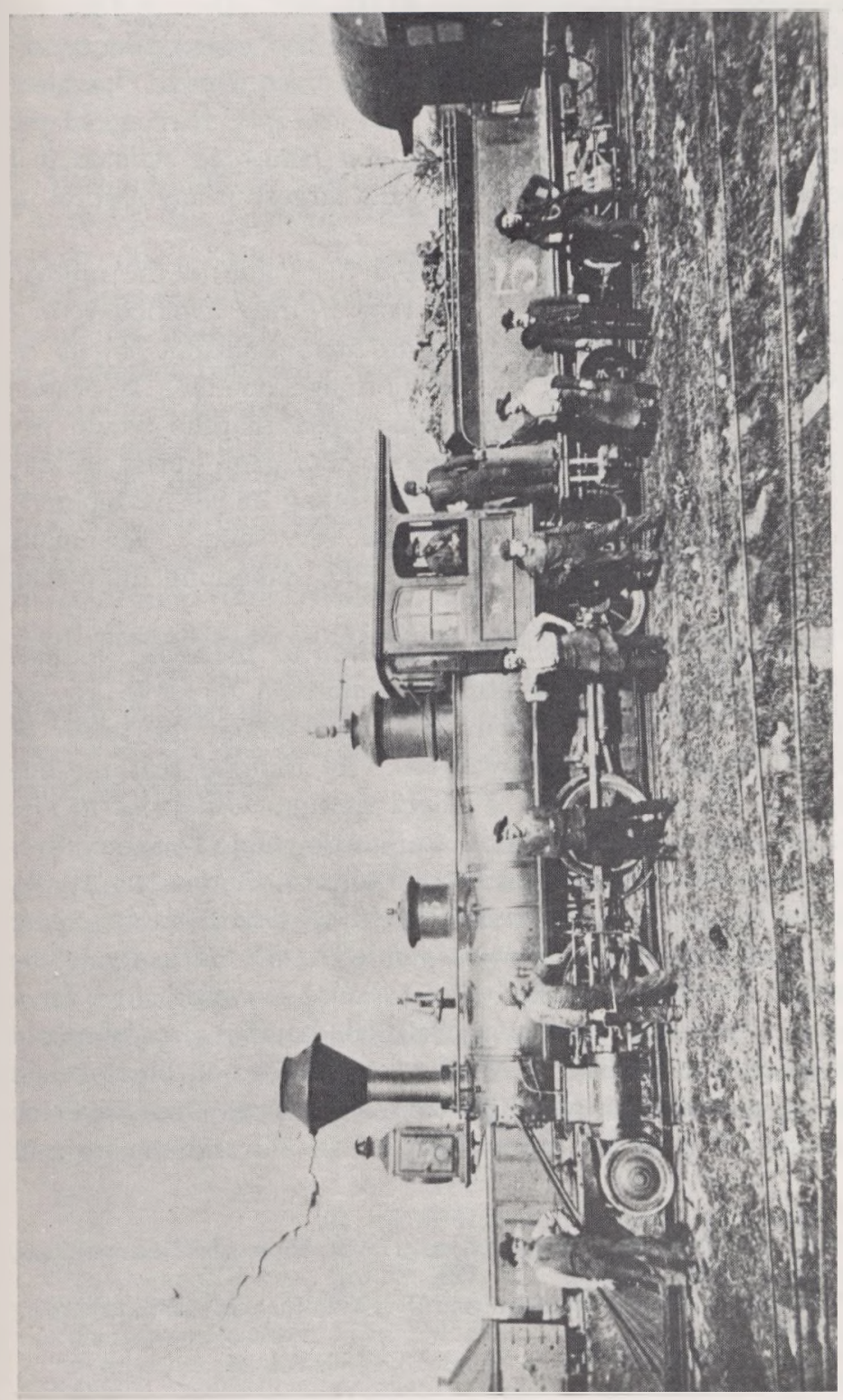

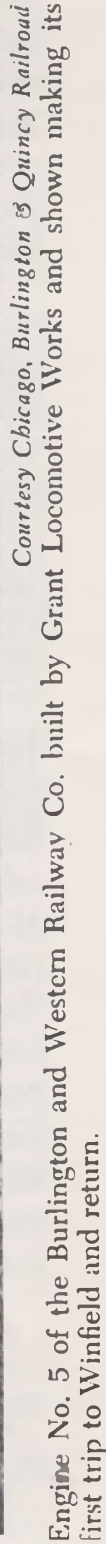


ceipts for the last week in November were $\$ 2,000,{ }^{38}$ and in = December, 1880 , they totalled $\$ 7,008.48 .^{30}$ During 1881 the railroad repaid more than five fold all the subscriptions, subsidies, or other aid that its backers had requested. Operating expenses were 57 per cent of total receipts, leaving 43 per cent for net income. The Burlington Hawkeye claimed that the net earnings of the line were the largest of any road of its length in the nation. ${ }^{40}$

These profits naturally increased the value of the railroad securities. Hedge told Mason that if they avoided serious accidents, earnings would be more than sufficient to pay interest on both first and second mortgage bonds. ${ }^{41}$ In March, 1880 , the company treasurer announced that he would pay nine months' interest due on second mortgage bonds on May 1. The first mortgage bonds were selling at 95 , he reported, and he expected them to be at par very soon. ${ }^{42}$ Eventually Mason sold his bonds at 105, clearing something more than $\$ 5,000$.

Although Mason declined re-election as president in June, 1880 , because of his health, he continued to serve as vice president and to be actively concerned about the future of the Burlington and Northwestern. He thought that the line might be extended from Winfield through Oskaloosa to Des Moines and from Burlington to Toledo, Ohio. ${ }^{43}$ Other Burlington-Northwestern officials tried to push the matter. W. W. Baldwin, one of the directors, went to Oskaloosa to confer with leading citizens, who responded enthusiastically to the project. Baldwin reported that Oskaloosa would vote for a $21 \%$ per cent tax producing $\$ 46,000$, having already raised $\$ 52,000 .{ }^{44}$ The Burlington-Northwestern board of directors had passed a resolution that the company would undertake the extension if it could secure $\$ 150,000$ in aid and the right of

${ }^{38}$ Mason Diary, November 25, 1880, Vol. 49.

${ }^{38}$ R. M. Green, Treasurer's Statement of Receipts and Disbursements, November 1880-November 1881, Vol. 35.

${ }^{40}$ Burlington Hawkeye, February 21, 1882; June 15, 1881; February 21,1880 .

${ }^{41}$ Thomas Hedge to Mason, March 13, 1880, Vol. 29.

${ }^{12}$ R. M. Green to Mason, April 12, 1880, Vol. 29.

${ }^{43}$ Mason Diary, November 16, June 15, September 30, 1880, Vol. 49.

${ }^{44}$ W. W. Baldwin to Mason, January 27, 1880, Vol. 29. 
way and station grounds. ${ }^{45}$ They proposed to build from Winfield or Mt. Union across the northern townships of Henry and Jefferson counties, then across the southwestern corner of Keokuk County, and to enter Mahaska County from the southeast. ${ }^{48}$

Although the Burlington-Northwestern never extended to Oskaloosa, the company fulfilled the same purpose by other means. They gave up the construction project to Oskaloosa in 1880 because the taxes voted there stipulated that the narrow gauge extension be completed by the end of the year. This the company believed it would be unable to do. ${ }^{47}$ The project was revived in 1881, however, with the incorporation of the narrow gauge Burlington and Western, Charles Mason being one of the directors. ${ }^{48}$ The new company completed the line from Winfield to Oskaloosa in 1884. The two companies then arranged their train schedules so that the Burlington and Western train from Oskaloosa met the southbound BurlingtonNorthwestern train at Winfield, thus providing narrow gauge service between Oskaloosa and Burlington. However, although the two lines sychronized their schedules so that they were virtually one system, each company retained its separate business identity. ${ }^{49}$

The narrow gauge railroads were largely superceded by standard gauge tracks because of economic factors. American freight consists of heavy, bulky products such as coal, timber, and petroleum. This requires large engines and cars in contrast to narrow gauge equipment which is light and small, designed to carry freight for short hauls. ${ }^{50}$ As a result, present narrow gauge track is confined to the mountain areas of the West and to limited regions in North Carolina, Tennessee, and Pennsylvania. ${ }^{51}$

45 Thomas Hedge to Mason, December 24, 1879, Vol. 29.

${ }^{48}$ Burlington Hawkeye, April 1, 1881.

${ }^{47}$ Thomas Hedge to Mason, February 18, 1880, Vol. 29.

${ }^{48}$ Burlington Hawkeye, August 24, 1881.

${ }^{49}$ Wilson, op. cit., p. 151.

${ }^{50}$ Harold Faulkner, American Economic History (New York, 1943), p. 504.

${ }^{51}$ Henry, op. cit., p. 37. 